\title{
Internationalization of the Taiwan Banking Industry, 1990-2001
}

\author{
Hsien-Jui Chung
}

\begin{abstract}
This article depicts and analyses the internationalization of the banking industry in Taiwan during the period 1999 to 2001 . We draw on the perspective of capabilities to describe and explain how banks' domestic operations experience prior to internationalization both restrained and contributed to overseas expansion. As a bank has an initial internationalization experience, domestic experience did not prejudice the subsequent internationalization.
\end{abstract}

Index Terms-Banking, industry internationalization, overseas expansion, capability development.

\section{INTRODUCTION}

International expansion is an accumulative process in which firms developed their international operation capabilities in a long period that are necessary for effective management of international businesses [1].

In this article we chart the course of Taiwan's banking industry to reveal how a highly domestic orientation displays the rudiments of internationalization. Many studies show that capability plays a significant role in internationalization. The unique ability has an important role in in driving bank internationalization [2]. Branch management capability of the Bank of Canada is an important factor in attracting customers [3]. The examination of internationalization of the banking industry in Taiwan reveals how an overly embedded domestic banking system launches the process of internationalization.

\section{AN OVERVIEW OF TAIWAN BANKING INDUSTRY}

In the third quarter of twentieth century governments imposed strict regulation on the banking industry driven by the belief that international finance lead to domestic macroeconomic instability [4]. The Kuomintang post-war government in Taiwan faced with rapidly increasing inflation adopted a similar strategy. As Kuomintang government moved from mainland China to Taiwan in 1949, seven stated-owned financial institutions accompanied with Kuomintang government also resume business in Taiwan. Kuomintang government faced fierce inflation both in the mainland China and Taiwan in 1945-1949. Therefore it strived to keep political stability and heavy regulation of the banking industry to enable economic growth. Regulation included controlled of bank deposits, interest rates and

Manuscript received October 19, 2013; revised December 20, 2013.

HsienJui Chung is with the Department of History, the Tsinghua University, Peking, 100084 China (e-mail: hj0730.chung@ gmail.com). operational procedures. Regulation, prior to 1991, had the effect of limiting the number of financial institutions and so the industry expanded as banks established new branches across the country. As a result incumbent banks earned significant profits in a closed and stable financial environment characterized by a low degree of competition

Government policy focused on creating a stable platform for economic development and this came at the expensive of considering internationalization. The Government's approach, initiated in 1970, was conservative and directed towards newly-established financial institutions including two overseas Chinese-funded banks (OCBC Bank and United Bank), two City-controlled Banks, an Export-Import Bank, a few private banks and a number of credit cooperatives. In other countries, such as South Africa and New Zealand, deregulation of the industry was having significant effects on the internationalization of banks [2]. The Government in Taiwan, similarly, faced increasing calls in the mid-1970s from the industry to engage in liberalization to facilitate internationalization.

The pressure for reform grew as financial liberalization became an international norm and a significant proportion of Taiwan's economic activity was export oriented. In 1984 the Government responded to these pressures and started to formulate a financial liberalisation policy.

TABLE I: TAIWAN BANKING INDUSTRY IN TERMS OF NUMBER OF BANKS AND THEIR DOMESTIC AND OVERSEAS BRANCHES

\begin{tabular}{l|c|c|c}
\multicolumn{3}{c}{ AND THEIR DOMESTIC AND OVERSEAS BRANCHES } \\
\hline Years & $\begin{array}{c}\text { Total number } \\
\text { of banks }\end{array}$ & $\begin{array}{c}\text { Total number of } \\
\text { domestic branch }\end{array}$ & $\begin{array}{c}\text { Total number of } \\
\text { foreign branch }\end{array}$ \\
\hline To 1990 & 28 & 1125 & 27 \\
1991 & 28 & 1198 & 33 \\
1992 & 42 & 1356 & 42 \\
1993 & 43 & 1507 & 50 \\
1994 & 43 & 1694 & 55 \\
1995 & 43 & 1925 & 60 \\
1996 & 43 & 2067 & 71 \\
1997 & 48 & 2313 & 102 \\
1998 & 49 & 2564 & 122 \\
1999 & 53 & 2748 & 131 \\
2000 & 54 & 2901 & 142 \\
2001 & 54 & 3007 & 149 \\
\hline
\end{tabular}

Source: Statistics of the Bureau of Monetary Affairs, Ministry of Finance in Taiwan, 1990-2001.

By 1988 a significant proportion of regulatory controls had been swept away. In a significant move the Ministry of Finance removed the restriction on the establishment of new banks. In 1989, the central bank began to put foreign exchange reserves in foreign branches of peer banks. This move enhanced their international competiveness and set the 
stage for the banking sector to increase the number of overseas branches from 27 in 1990 to 149 by the end of 2001 . Table I shows the position of the banking industry by 2001 in terms of foreign and domestic and banks.

\section{THE INTERNATIONALIZATION BEHAVIOR OF TAIWAN BANKING INDUSTRY}

Each bank draws on different capabilities and so their response to liberalisation of the industry varied. We analyse and illustrate post-liberalization behaviours of different banks with various capabilities in this section.

TABLE II: THE DOMESTIC BRANCH EXPERIENCE AMONG BANKS WITH DIFFERENT FOREIGN BRANCH EXPERIENCES AND BEHAVIORS

\begin{tabular}{|c|c|c|c|c|c|}
\hline \multirow[t]{2}{*}{ Years } & \multirow{2}{*}{$\begin{array}{l}\text { Bank } \\
\text { category }\end{array}$} & \multirow{2}{*}{$\begin{array}{l}\text { Number } \\
\text { by } \\
\text { category }\end{array}$} & \multicolumn{3}{|c|}{ No. of domestic branches } \\
\hline & & & Average & Minimum & Maximum \\
\hline \multirow[t]{4}{*}{1991} & $n \mathrm{OB}$ & 19 & 27.42 & 1 & 101 \\
\hline & $t \mathrm{OB}$ & 2 & 53.00 & 38 & 68 \\
\hline & OB & 3 & 19.67 & 2 & 37 \\
\hline & at $\mathrm{OB}$ & 4 & 109.75 & 92 & 125 \\
\hline \multirow[t]{4}{*}{1992} & $n \mathrm{OB}$ & 31 & 14.74 & 1 & 99 \\
\hline & $t \mathrm{OB}$ & 2 & 57.50 & 14 & 101 \\
\hline & $\mathrm{OB}$ & 5 & 53.40 & 2 & 128 \\
\hline & at $\mathrm{OB}$ & 4 & 89.75 & 39 & 116 \\
\hline \multirow[t]{4}{*}{1993} & $n \mathrm{OB}$ & 30 & 18.43 & 1 & 102 \\
\hline & $t \mathrm{OB}$ & 2 & 15.00 & 9 & 21 \\
\hline & OB & 5 & 70.20 & 2 & 129 \\
\hline & at $\mathrm{OB}$ & 6 & 70.33 & 16 & 121 \\
\hline \multirow[t]{4}{*}{1994} & $n \mathrm{OB}$ & 30 & 22.03 & 1 & 104 \\
\hline & $t \mathrm{OB}$ & 0 & n.a & n.a. & n.a. \\
\hline & OB & 9 & 57.89 & 2 & 119 \\
\hline & at $\mathrm{OB}$ & 4 & 81.25 & 20 & 132 \\
\hline \multirow[t]{4}{*}{1995} & $n \mathrm{OB}$ & 29 & 23.38 & 1 & 86 \\
\hline & $t \mathrm{OB}$ & 1 & 112.00 & 112 & 112 \\
\hline & OB & 9 & 68.44 & 2 & 137 \\
\hline & at $\mathrm{OB}$ & 4 & 72.00 & 24 & 124 \\
\hline \multirow[t]{4}{*}{1996} & $n \mathrm{OB}$ & 29 & 27.97 & 1 & 92 \\
\hline & $t \mathrm{OB}$ & 0 & n.a. & n.a. & n.a. \\
\hline & OB & 9 & 81.22 & 2 & 140 \\
\hline & at $\mathrm{OB}$ & 5 & 76.60 & 18 & 144 \\
\hline \multirow{4}{*}{1997} & $n \mathrm{OB}$ & 31 & 22.90 & 1 & 70 \\
\hline & $t \mathrm{OB}$ & 3 & 61.30 & 20 & 95 \\
\hline & OB & 9 & 80.44 & 2 & 137 \\
\hline & at $\mathrm{OB}$ & 5 & 89.80 & 32 & 151 \\
\hline \multirow[t]{4}{*}{1998} & $n \mathrm{OB}$ & 30 & 28.20 & 1 & 74 \\
\hline & $t \mathrm{OB}$ & 2 & 24.50 & 24 & 25 \\
\hline & OB & 9 & 88.22 & 2 & 148 \\
\hline & at $\mathrm{OB}$ & 8 & 78.00 & 24 & 155 \\
\hline \multirow[t]{4}{*}{1999} & $n \mathrm{OB}$ & 33 & 29.76 & 1 & 77 \\
\hline & $t \mathrm{OB}$ & 1 & 24.00 & 24 & 24 \\
\hline & OB & 14 & 88.86 & 3 & 165 \\
\hline & at $\mathrm{OB}$ & 5 & 62.80 & 27 & 143 \\
\hline \multirow[t]{4}{*}{2000} & $n \mathrm{OB}$ & 34 & 32.26 & 1 & 79 \\
\hline & $t \mathrm{OB}$ & 0 & n.a. & n.a. & n.a. \\
\hline & OB & 14 & 77.79 & 3 & 150 \\
\hline & at $\mathrm{OB}$ & 6 & 93.67 & 33 & 169 \\
\hline \multirow[t]{4}{*}{2001} & $n \mathrm{OB}$ & 33 & 34.88 & 1 & 83 \\
\hline & $t \mathrm{OB}$ & 1 & 33.00 & 33 & 33 \\
\hline & OB & 16 & 84.56 & 30 & 163 \\
\hline & at $\mathrm{OB}$ & 4 & 91.00 & 3 & 181 \\
\hline
\end{tabular}

Our observations start in 1991 and continue over a ten year period. We examined four category of banks based on their position in each year of observation: banks without overseas branches (category $n \mathrm{OB}$ ); banks that established their first overseas branch in year $(t)$ (category $t \mathrm{OB}$ ); banks with overseas branches (category OB), and banks who already had overseas branches but also expanded this network in year $(t)$ (category atOB). To avoid confusion, if a bank established but did not setup its first foreign branch in year $(t)$ we classified it as category $t \mathrm{OB}$ in year $\mathrm{t}$ and as category $\mathrm{OB}$ in year $(t+1)$. Table II gives details for each category.

Our analysis is motivated to answer the following central question: in what way does banks' domestic branch experience influence them to establish overseas branches? We analyse our central question from three perspectives. First, does domestic branch experience help to establish the first overseas branch? Second, why do some banks elect not to expand overseas? Third, does extensive domestic branch experience hinder the establishment of overseas branches?

\section{A. Does Domestic Branch Experience Help to Establish the First Overseas Branch}

As domestic branch experience increases so it facilitates inter-unit coordination capabilities and this enables the exploitation and development of knowledge that can facilitate the launch of overseas branches [5]. Banks, following this rational, that are capable of establishing overseas branches should have more domestic branches than those without overseas branches. I compared observations of category $n \mathrm{OB}$ and $t \mathrm{OB}$ banks to explore this issue. During the 11 year period of observations, there were no category $t \mathrm{OB}$ observations in the years 1994, 1996 and 2000 (See Table II). The average numbers of domestic banks categorized as $t \mathrm{OB}$ were significantly higher than those categorized as $n \mathrm{OB}$ in 1991, 1992, 1995 and 1997 and were only slightly less in 1993, 1998, 1999 and 2001. Banks, prior to the establishment of their first overseas branch, had at least nine and an average of 46.6 domestic branches. These results suggest banks entering international market still needed substantive domestic operation experience.

The notion of multiunit operational knowledge qualifies our findings. Banks with more domestic branches are able to generate multiunit operational knowledge that is necessary for international operations. This capability enables integration of overseas subsidiaries into the firm and so makes the process of entering foreign markets easier [6].

\section{B. Why do Some Banks Elect not to Expand Overseas}

We find 33 banks not engaged in overseas markets (See Table II). We find category $n \mathrm{OB}$ observations are significantly greater than those of category $t \mathrm{OB}$ in 1991, 1993, 1998, 1999 and 2001. This shows that banks with a large number of domestic branches delayed their progress to internationalization. This phenomenon is not unique to Taiwan. British banks faced difficulties in entering overseas markets as they were constrained by their conservative traditions that revolved around their domestic branch operations [7].

Our findings suggest that internationalization is both facilitated and hindered by domestic branch experience. Where domestic branch operations are extensive this has a negative impact on banks' willingness to expand overseas. This fits with arguments that as capabilities supporting a category of operation become embedded in a firm they preclude alternative ways of operating [8]. Domestic branch 
experience while fostering multiunit operational capability also develops a strong domestic-oriented dominant logic which prevents banks from entering overseas markets. This lack of attention on overseas expansion arises because of a domestic, repetitive momentum [9].

Firms whose growth strategy focuses on domestic expansion are likely to be biased towards a domestic oriented strategic commitment [10]. This momentum is reinforced in the development of capabilities and mental maps that are only suitable for domestic operations. Adaptation of the domestic orientation of these mental maps and capabilities is difficult but required for overseas [11].

\section{Does Extensive Domestic Branch Experience Hinder the Establishment of Overseas Branches?}

We find a correlation of 0.42 (significant at the $p<0.05$ level) between the number of domestic and foreign branches (See Table II). Our results raise an important question: if a large number of domestic banks did not favour establishing overseas branch then while are numbers of branches (domestic and overseas) positively correlated?

While both category $\mathrm{OB}$ and at $\mathrm{OB}$ have overseas branches the former did not establish foreign operations in year $(t)$. A comparison between category $\mathrm{OB}$ and at $\mathrm{OB}$ observations in Table II shows that, apart from in 1991, they both have virtually the same maximum numbers of domestic branches. This infers that significant levels of domestic branch experience do not necessarily equate with a strong domestic inertia if banks have overseas branch experience. The minimum numbers of domestic branches, however, of category $\mathrm{OB}$ observations are less than those of category atOB (except for 2001). There are two implications of these results. First, for those banks that already had overseas branch(es) then a large number of domestic branches did not limit their expansion. Second, those categories of banks with foreign branch experience (i.e., $\mathrm{OB}$ and $a t \mathrm{OB}$ ) had a different approach to expansion than those without overseas branches (i.e., $n \mathrm{OB}$ and $t \mathrm{OB}$ ).

Our analysis provides useful insights into the internationalization process of banking in Taiwan. When banks started shortly after industry liberalization and then continued overseas expansion they established an internationalization capability that facilitated their continued expansion. Those banks whose emphasis lay with the establishment of domestic branches encountered obstacles when they attempted to expand overseas. When banks had foreign branch experience then a large number of domestic branches did not hinder subsequent internationalization.

\section{CONCLUSIONS}

In this study I examine internationalization and how this relates to the development of a specific capability in the banking industry in Taiwan. Our findings reveal three implications relating to: the formation of internationalization ability, the rigidity of the domestic operations capability and the reconfiguration of an internationalization capability. This study shows that domestic operational experience is an important source of internationalization ability. It suggests that the capability of multiunit coordination facilitates entry to overseas markets.

Even when an industry begins to liberalize not all firms can internationalise. Domestic branch experience may translate into a form of domestic oriented inertia that precludes foreign expansion. Foreign expansion, for firms in emerging economies, is often an alternative to domestic geographic market entries. Some firms even focus on domestic segments to avoid competition from multinational enterprises [12]. Therefore, excessive domestic branch experience prior to internationalization restrains foreign expansion and retards industry internationalization.

Firms have the opportunity to expand in both domestic and overseas markets simultaneously. According to the evolutionary theory of the firm [13], a firm's capabilities are accumulated [14]. A firm is an expanding repertoire of knowledge so that prior experience influences succeeding decisions [15]. Firms are social communities that serve as efficient mechanisms for the creation and transformation of knowledge [16]. Entry to foreign markets needs not only creation and accumulation of new knowledge but also replication and application of existing knowledge in multiple locations [17]. This occurs when routines associated with overseas market entries interweave with those associated domestic market entries and new capabilities emerge.

\section{REFERENCES}

[1] J. Johanson and J. Vahlne, "The Internationalization process of the firm: a model of knowledge development and increasing foreign commitments," Journal of International Business Studies, vol. 8, no. 1, pp. 23-32, 1977.

[2] J. Singleton and G. Verhoef, "Regulation, deregulation and internationalization in South African and New Zealand banking," Business History, vol. 52, no. 4, pp. 536-563, 2010.

[3] J. L. Darroch, "Global competitiveness and public policy: the case of Canadian multinational banks," Business History, vol. 34, no. 3, pp. 153-175, 1992.

[4] E. Helleiner, States and the Reemergence of Global Finance from Bretton Woods to the1990s, Ithaca: Cornell University Press, 1994.

[5] E. Mosakowski and S. Zaheer, "The global configuration of a speculative trading operation: an empirical study of foreign exchange trading," Organization Science, vol. 10, no. 4, pp. 401-423, 1999.

[6] S. Ghoshal and C. A. Bartlett, "The multinational corporation as an interorganizational network," Academy of Management Review, vol. 15, no. 4, pp. 603-625, 1990.

[7] P. L. Cottrell, "London financiers and Austria 1863-1875: the Anglo-Austrian bank," Business History, vol. 11, no. 2, pp. 106-119. 1969.

[8] R. A. Bettis and C. K. Prahalad, "The dominant logic: retrospective and extension," Strategic Management Journal, vol. 16, no. 1, pp. 5-14, 1995.

[9] T. L. Amburgey and A. S. Miner, "Strategic momentum: the effects of repetitive, positional, and contextual momentum on merger activity," Strategic Management Journal, vol. 13, no. 5, pp. 335-348, 1992.

[10] B. Mascarenhas, "International strategies of non-dominant firms," Journal of International Business Studies, vol. 17, no. 1, pp. 1-25, 1986.

[11] F. Vermeulen and H. Barkema, "Pace, rhythm, and scope: process dependence in building a profitable multinational corporation," Strategic Management Journal, vol. 23, no. 7, pp. 637-653, 2002.

[12] R. E. Hoskisson, L. Eden, C. M. Lau, and M. Wright. "Strategy in emerging economies," Academy of Management Journal, vol. 43, no. 3, pp. $249-267,2000$

[13] R. R. Nelson and S. G. Winter, An Evolutionary Theory of Economic Change, MA: Harvard University Press, 1982.

[14] M. Zollo and S. G. Winter, "Deliberate learning and the evolution of dynamic capabilities," Organization Science, vol. 13, no. 3, pp. 339-351, 2002. 
[15] A. Verbeke, "The evolutionary view of the mne and the future of internalization theory," Journal of International Business Studies, vol. 34, no. 6, pp. 498-504, 2003.

[16] B. Kogut and U. Zander, "Knowledge of the firm and the evolutionary theory of the multinational corporation," Journal of International Business Studies, vol. 24, no. 4, pp. 625-645, 1993.

[17] E. T. Penrose, The Theory of the Growth of the Firm, New York: Oxford University Press, 1959
Hsien-Jui Chung was born at Taiwan. He earned $\mathrm{Ph}$. D. in management 1999 from National SunYat-Sen University, Kaouhsiung, Taiwan. He is currently a doctoral student of Department of History, the Tsinghua University in Peking. His research interests include organizational evolution and business history. Mr. Chung is also a member of AOM. 